\section{Relacional: Easing the Crisis Effects in the Education Sector}

\author{
Relacional: Amenizando os Efeitos da Crise no Setor da Educação
}

Discipline: Business Strategy, Product and Service Innovation

Subject: Digital platforms, Software versioning

Industry: Education Sector, Information Technology

Geography: São Paulo/Brazil

Adrian Kemmer Cernev*1 $\odot$

Letícia Fantinato Menegon ${ }^{1,2}$

Marta de Campos Maia ${ }^{10}$
By the end of an exhaustive meeting, back in May 2020, Relacional's partners André, Rafael, and Vivian had not yet found a common ground about running the business against the backdrop of a war imposed by the COVID-19 pandemic in March of that year.

Relacional is a software company that provides digital relationship management between students and educational institutions. Founded in 2014, it grew fast following dramatic changes in the rules of Brazil's Student Loan Fund (in Portuguese, Fundo de Financiamento Estudantil - Fies). At the end of that year, the Brazilian Ministry of Education cut down the vacancies for Fies, which severely affected enrollment in higher education institutions (HEIs). Several low-income students were no longer eligible for funding, thus making access to those

* Corresponding Author.

1. Fundação Getulio Vargas, Escola de Administração de Empresas de São Paulo, São Paulo, SP, Brazil. 2. Escola Superior de Propaganda e Marketing, São Paulo, SP, Brazil. Cite as: Cernev, A. K., Menegon, L. F., \& Maia, M. de C. (2021). Relacional: Easing the crisis
effects in the education sector. Revista de Administração Contemporânea, 26(1), e200377. https://doi.org/10.1590/1982-7849rac2022200377.en institutions impossible at times. This scenario favored Relacional because, without Fies, higher institutions had to attract and keep students. By themselves, these institutions would have difficulties establishing this relationship due to their lack of experience and dedicated staff.

The year 2020 had already been challenging for the company, considering the entry of international competition and the strengthening of domestic competitors. However, the pandemic posed a bigger challenge: to face the downfall of educational institutions and their customers, who have suffered major setbacks since the beginning of the pandemic, such as increased default on fees and dropout rates, and a drop in student enrollment and re-enrollment for the second semester.

\begin{tabular}{|c|c|c|c|c|c|c|c|c|c|}
\hline \multicolumn{10}{|c|}{$\#$ of invited reviewers until the decision: } \\
\hline & 1 & 2 & 3 & 4 & 5 & 6 & 7 & 8 & 9 \\
\hline $1^{1 \text { t }}$ round & 2 & $\stackrel{9}{2}$ & & & & & & & \\
\hline $2^{\text {nd }}$ round & $\stackrel{8}{2}$ & $\stackrel{8}{2}$ & & & & & & & \\
\hline $3^{\text {rd }}$ round & $\stackrel{\infty}{2}$ & & & & & & & & \\
\hline $4^{\text {th }}$ round & $\stackrel{9}{=}$ & & & & & & & & \\
\hline
\end{tabular}


Faced with this scenario of uncertainty and several changes, Relacional had to adapt. The biggest challenge presented to the partners was to reflect on how the company's technology could continuously contribute to the education market, without burdening it and avoiding revenue loss, since the education industry was holding down expenditures.

It was a set of complex decisions amidst a turbulent scenario. Relacional's partners could not close that meeting without answering the questions posed by each of them: Should we version the software, selling it in parts, to enable cheaper sales? How can we make our system less costly and solve the specific pains of this market, without the need for long implementation and without hampering the entire product?

As the second school semester approached, with new student enrollment processes and the re-enrollment period, the answer to these questions pointed to the safest way for Relacional's business to survive.

\section{THE BUSINESS IDEA}

The year 2010 was crucial for André. He had built his career as an executive in renowned international companies, with an emphasis on the technological area, while his entire agenda was closely related to the education sector. Married for eight years, he started to feel his wife's pressure to have children. At the same time, he questioned himself about the direction he would take in his career. Those decisions were hard to make without enough discussions. Then, they decided to take a sabbatical year instead of buying an apartment. They traveled and studied in London and, during a short study trip to the United States of America, they came into contact with an old model of student loan, which did not prove to be very efficient. This model was the same that has been used in Brazil since 1999, when the Higher Education Loan Funding (in Portuguese, Fundo de Financiamento ao Estudante do Ensino Superior) was created - later renamed as Fies. This funding aims to finance the undergraduate course of students enrolled in private HEIs with a positive evaluation according to the Ministry of Education's evaluation processes.

André returned to Brazil in 2011 thinking: "This financing model is going to break. It is not sustainable, because other countries have already tried it, and it didn't work. One day this source will dry up."

Having worked in the education industry, he knew that the market had many academic management solutions. But he knew that none of them focused on relationship management for attracting and retaining students with a simultaneous commercial and marketing point of view. "I saw an opportunity in the Fies model and placed my bet: it will end, and when it does, colleges will not be prepared to perform marketing, commercial, and customer acquisition. They will need technology and methodology applied to this," said André.

It took him three years to mature the idea. In 2014, he eventually left the company where he worked and founded Relacional, a company whose name referred to the relationship and the education industry. Without having a product, he created a blog in which he addressed issues such as technology for student acquisition and educational marketing. At the same time, he began to design a product, a comprehensive customer relationship management system (CRM) focused on the education industry. Meanwhile, he realized the need for complementary skills in the team of the great company he was imagining. He invited two other people to be his partners, with whom he had worked in the past: Vivian, who had experience in the education market and good financial vision, and Rafael, who had a technical profile, given his background in computer science and experience in software development for education. Both accepted the challenge.

\section{FROM THE BEGINNING OF OPERATIONS TO RELACIONAL'S GROWTH}

The prototype of the technology that would encompass Relacional's operations started being designed when the two partners joined the company in 2014. The technology needed to be quickly developed and tested, as they imagined a fast change in Fies would take place by the end of former Brazilian president Dilma Rousseff's second term, and they needed to set up their business' growth.

At that time, the most accessible customer relationship management technology available in Brazil was Microsoft's CRM. They customized the tool for the education market, since they understood that building a technology from scratch would take at least two years.

They spent the second half of 2014 testing the minimum viable product (MVP) and had the opportunity to make several adjustments. In addition, they were acquiring some important clients. "We were doing the first MVP, testing and checking how good it was. Then, at the end of the year, Roussef completely changed the rules of the Fies game, which greatly affected education institutions. Many of them were in the following situation: between $30 \%$ and $50 \%$ - and in some cases, up to $70 \%$ — of their student acquisition was related to 
Fies, that is, their revenues were practically coming from this type of funding. Overnight, the institutions lost this acquisition, because the government reduced considerably the vacancies available for funding," said Vivian.

The essence of the company's system was in attracting students, which covered lead management ('lead' is used to describe a potential customer interested in the product or service of a company), the application process, admission test, enrollment, and automated scales. The pricing model was based on an initial setup fee (software configuration and user training) and a monthly license and support fee. The prices were directly negotiated with each customer, without a fixed pricing table. Relacional's sales team would evaluate the needs and the size of an institution to estimate the parameters for price composition.

Despite being in the testing phase, Relacional observed an unexpected boom in 2015. This was due to the lack of a specific software program for attracting and retaining students in the Brazilian market.

In the following years, the company grew fast: "By the end of 2015, we acquired some important clients that helped us in this initial leverage. Over the years, we grew exponentially. Throughout 2016, we doubled our customers and revenue. We doubled our revenue again in 2017 and 2018. It was some considerable growth. The company kept growing and the market demanded a lot. We accessed large education groups, which helped us a lot to increase our capillarity throughout Brazil. We went from a business with only three partners to a company of 50 employees," explained Vivian.

But they knew that all of this was a phase of the market and that they would need to prepare for the next challenges. To do so, they became more involved with the innovation and entrepreneurial ecosystem.

In 2016, they took part in the Stanford University Innovation and Entrepreneurship Program, held by the government of Minas Gerais, in conjunction with the FIEMG System, BID, Sebrae Minas, BDMG, and the Belo Horizonte City Hall. "That moment was of fundamental change for the company, as we started to access the entrepreneurial mindset," declared André.

In 2017 and 2018, Relacional joined the ScaleUp Program by Endeavor, a major entrepreneurship support organization.

In 2018, a national software company, which offered CRM services for several segments, probably observing Relacional's growth, sought to position itself in the CRM segment for the education industry. It acquired part of a CRM company that was starting its operations in the education market.
In the same year, observing its customers' needs, and looking for a new competitor, Relacional launched an additional component to its CRM system: the student permanence module, focused on monitoring the evolution of a student's success, because Relacional understood that problems arising from this situation would reflect directly on the dropout rate. "What's the point of putting a lot of effort into attracting [students] if, at the end of the day, they are leaving?" asked André.

According to data from Inep (the Anísio Teixeira National Institute of Educational Studies and Research), Brazilian universities have, on average, a $21 \%$ dropout rate. Depending on the course method and student profile, this number can reach up to $40 \%$. "I found out that, to deal with permanence, you have to poke the bear. You have to deal with everything from cold food in the cafeteria to the students' score on Enade (the Brazilian Student Proficiency Exam). Everything in between impacts dropout and permanence. We started to realize that every college in the world wants to reduce dropout, but they have a hard time getting started," said André.

The permanence module was launched in 2018, but the market did not initially embrace it. The partners then realized that they would have to simplify it so that educational institutions could take the first step to adopt it. To do so, the company focused on a single issue to leverage student permanence: relationship. Other issues from the first version of the permanence module were left out for a future stage, and Relacional believed that its customers would notice its value eventually.

In the drive to understand how the international market was behaving regarding the issues the partners observed among their Brazilian clients - and also to understand how they could add more value to their system - , they attended, in late 2018, the Web Summit in Portugal - the largest technology event in the world, where CEOs and founders of technology startups met, as well as people from the global technology industry. This event was game-changing, as Relacional's partners realized that they could apply even more technology to improve their clients' results.

It was then that they began to work with artificial intelligence and prediction modeling, considering the possibility of integrating them with the existing system modules.

One of the predictive models was lead scoring, i.e., "with a given lead, I can predict the chance of them taking the admission test and their chance to enroll in the course. Then, I get that candidate's score, which estimates the percentage probability of that person enrolling," explained Rafael. 
Another predictive model was the dropout, which could also be integrated into the permanence module of the operating system. "Given a student's behavior, I can predict a student's probability of dropping out that semester. I use internal and external variables to estimate this," demonstrated Vivian.

In realizing the value of these predictive models to customers, the partners considered the possibility of marketing them in a different way, both in design and pricing. "We usually break CRM down into two subproducts: attracting and retaining students, and we even sell them separately. We then realized that we could sell the prediction models independently from the CRM system, because the predictive model can be used by any educational institution, whether they use our system or not," said André.

As for selling the prediction model independently from Relacional's CRM system, the institution would need to make data from other internal systems available electronically, including another CRM system already in operation.

The prediction model for acquiring leads had unique features: instead of being sold by a monthly fee, the pricing would be based on processed leads. To make it work well, Relacional built APIs (application programming interfaces) to interconnect systems: the education institution would send leads electronically. Those leads would be processed by Relacional in a cloud computing model and, then, returned to the client with the respective scores. Each client would have an exclusive prediction model, with variables and scales adjusted to the context of that institution. Even with remote lead processing, the data would remain as exclusive property of the education institution and would need protection during the entire interaction with Relacional. "We realized that a generic template would not be enough to solve the client's problem, so we ended up building a template for each institution. This is a new product we started testing in the second half of 2018 and it went very well," explained Rafael.

The year 2018 had already been quite challenging for Relacional's partners in terms of product and service development. But a new change was yet to come: in the middle of the second half of 2018 they were approved to be part of Cubo Itaú - Latin America's largest and most relevant technology entrepreneurial center. Cubo's declared goal is to connect entrepreneurs, large companies, investors, and universities in one place to discuss technology, innovation, new business models, new ways of working, and how to challenge the status quo.

The company's admission into Cubo Itaú's ecosystem was quite successful: in 2019, Relacional had net sales of R \$
$2,250,000$, with a net income after taxes of approximately $\mathrm{R} \$ 530,000$ (23.5\%), which were almost fully reinvested in the business. This represented a rate of about $65 \%$ growth over the previous year's sales, something relatively uncommon even among startups.

The educational market itself was booming, with a growth of $37.5 \%$ in the number of active institutions in the country in 2019 alone. Moreover, since 2010 the number of students enrolled in higher education in Brazil has been growing at around 6\% per year, even in periods of crisis. A major highlight has been the growth in distance learning, at a rate of $20 \%$ per year over the same period. In 2019 , approximately $40 \%$ of active students were enrolled in the online model.

At the end of 2019, the company was ranked among the 10 best companies to work for in the state of Minas Gerais, Brazil, in the Great Place to Work ranking, which awards the Best Companies to Work for at the national, regional, sectoral, and thematic levels.

\section{0, A YEAR OF DEEP CHANGES FOR RELACIONAL}

The year 2020 started out busy, with a more prominent presence of an international competitor in the market, offering a set of technological solutions that helped education institutions in their relationship with students.

In this year, Relacional served about 230 education institutions in Brazil, in more than 20 states, from elementary school to higher education - the latter making up the majority of clients. The company's slogan was: "management from lead to enrollment and from enrollment to diploma."

Relacional was among the five largest software and service providers in the education market, with about $15 \%$ of the market. In the specific niche of software for HEIs that are not part of large education groups, the company's market share was close to $20 \%$. However, the potential market is even more expressive, since more than half of the HEIs that do not belong to large education groups did not have an implemented CRM system by 2019, and worked with isolated information systems and/or spreadsheets.

Relacional's competitive environment is relatively heterogeneous. There are two large competitors, operating in multiple markets, with expressive power in investment, technical and commercial teams, and scale gains. There are also small companies, mainly startups, that in general tropicalize foreign technologies or are still in the MVP phase in the country. Only one small direct competitor 
had an exclusive focus on the education market in the first semester of 2020.

The three partners knew it would be a challenging year, as they were already facing major players in the market, such as Microsoft and Salesforce. By the end of January, they were reviewing their growth projections and working on meticulous planning. The year was promising, but they did not know what was yet to come: the COVID-19 pandemic and the consequent social isolation.

Although the company's head office is in Belo Horizonte, Minas Gerais, one of the partners, André, was mostly based in São Paulo. Since the company's conception, its partners and employees were used to a hybrid work system: two days working at the company's head office and three days working from home. Therefore, remote meetings and work were a reality for the team.

Because of the pandemic evolution in Brazil, the partners decided to hold a meeting with the whole company, with the main purpose of addressing prevention practices and hygiene against the new virus. It was March 12, a Thursday.

On March 19, André joined a meeting at Cubo that would set the tone for the coming months. "I had a reality shock! Several founders were there. Flávio Pripas, CEO of Cubo Itaú, who led the meeting, pointed us to a war scenario. We were supposed to prepare for a chaotic situation. I was stunned for a couple of days. It was then that Rafael, Vivian, and I got together to decide how we would face the new reality," André explained.

The partners got together and drew three scenarios: a realistic, an optimistic, and a pessimistic scenario. They created four indicators to analyze each scenario: fee default, contract termination, social isolation period, and working capital needs.

They started monitoring them and, since then, they do it almost on a daily basis, aiming at a vision of, at most, one month ahead. Furthermore, they have considered in their analyses education market indicators such as industry default, dropout rates, the possible decrease in acquisition, and re-enrollment in 2020-2. This market was expected to suffer greatly, given that many people were losing their jobs due to the pandemic, and not all students would adapt to the remote learning model.

In a conversation with an education specialist, the partners were told that by May 2020 around 265,000 students in Brazilian private universities had dropped out of their courses or took a leave of absence, and this year's dropout rate was 32\% higher than last year's. But the outlook for the second semester was even worse for universities, as a reduction of new students of 70 to $80 \%$ was predicted, which may lead many institutions to close their doors. For kindergartens, elementary schools, and high schools, the outlook does not look good as well, because $95 \%$ of them have already lost enrollments. In addition, schools also suffer from default and delays in tuition fees, which is a direct impact of unemployment and income decrease in Brazilian families.

The greatest concern of the three young entrepreneurs, faced with this context, was how to adapt quickly.

In the first week of social isolation, Relacional cut expenses, reduced investments - mainly in marketing events, that probably would not take place - , and reviewed all sales goals, imagining that few educational institutions would make new investments in that moment of crisis and uncertainty.

After this first demanding phase, they began to reflect on how Relacional's technology could contribute to the education market in that unusual context, without increasing the costs too much. "We needed to simplify our products, offer something cheaper, faster to implement, simpler to use, and that can reach other client groups, who have specific pains to be solved," reflected Rafael.

They came to the conclusion that they could offer a small part of their system, free of charge, to any education institution in Brazil. They made their Vestibular Digital (in English, Digital Admission Test) available, free of charge, to any college, thus acquiring almost 30 new education institutions. But the partners were still debating whether this short-term strategy could ease their clients' pains, or whether it was worth having a basic version to speed up new client acquisition. "I remember that, in a meeting with the crisis management committee, our sales head talked about the possibility of offering something similar to the free Vestibular Digital, but charging less than the usual price. I realized that he was talking about exactly the same thing Rafael had been talking about. In summary, it was versioning our product in order to meet the different market needs," said André.

As of this experience, the partners started to analyze which small parts of their comprehensive system could be encapsulated and sold differently: cheaper, without the need for a long implementation project, and that would solve very specific market pains. "We saw a great opportunity to reach a market of educational institutions that were much smaller than the ones we were working with, offering a leaner and cheaper product, which does not have such a high setup price. We sold this basic version of our product and launched for our client in ten days, something we had never been able to do," said Rafael. 
But there was still a question, which was expressed by the three partners, especially by André: "Could there be any cannibalization between the product's versions? How would the sales team deal with this new range of offers and prices? Furthermore, we think that this movement could cause a decrease in the company's income, that is, fewer sales of the full, more expensive system."

Rafael and Vivian pointed out: "How many products could we develop? Which functions and services would they have? The main idea was to develop simpler, cheaper, and faster-to-implement products."

From this experience, the partners also began to question whether the student permanence product was trying to solve a too broad pain and, therefore, making it difficult to get the product on the market.
They met other times. Vivian said: "Would it be possible to transform a large, full system into smaller products, delivering it differently? Could the large modules coexist and be versioned into smaller products to solve specific customer issues?"

André continued: "Even further: Is this new model an answer to the context of the COVID-19 pandemic or will it be permanent? Once versioning is implemented, can we go back to the previous sales model? What about technical support if we have a lot of customers with the new versions? We had a very intense meeting. We finished it without many answers," said André.

The imminence of the second school semester, with new enrollment processes and the student re-enrollment period, made these issues even more important, and Relacional would again need to anticipate its clients' problems. 


\section{APPENDIX A. TIMELINE AND PRODUCTS OFFERED BY RELACIONAL}

2014: Start of Relacional's operations with an educational blog;

2014: Development of the MVP of the CRM system for student acquisition;

2015: Sales growth;

2016: Participation in the Stanford University Innovation and Entrepreneurship Program;

2017: Participation in Endeavor's ScaleUp Program;

2018: Addition of the CRM system for student retention to the product line;

2018: Development of artificial intelligence and testing of new lead scoring and dropout predictive models, integrated or not with other CRM systems;

2018: Admission as a resident startup at Cubo Itaú;

2019: Marketing a product line encompassing the Student Acquisition CRM, Student Permanence CRM, Lead Scoring Module, and the Dropout Prediction Module;

2020: COVID-19 global pandemic declared on March 11, 2020;

2020: Launch of the Vestibular Digital module free of charge. 


\section{Teaching Notes}

\section{ABSTRACT}

This teaching case addresses the need for change in Relacional's business strategy, driven by the negative effects of the COVID-19 pandemic in the Brazilian educational sector in the first half of 2020. The startup is a software warehouse whose systems seek to solve specific problems of educational institutions, from basic to higher level, such as relationship, attraction, and retention of students. In the midst of a scenario of probable crisis in the sector, the partners seek business alternatives to assist educational institutions while wanting to ensure the growth and continuity of the company itself. Applicable in Entrepreneurship, Marketing, and IT courses in undergraduate and graduate Business Management programs, this case addresses concepts of Information Economy, models of offer and pricing of software.

Keywords: information technology; CRM; education; software versioning; software as a service.

\section{LEARNING OBJECTIVES}

By reading and discussing this case, participants will be able to: (a) identify and analyze strategic alternatives for startups in a context of uncertainty or crisis, considering their skills, limitations, and competitive advantages; and (b) assess different software distribution models and their implications for the business, applying, for this purpose, specific concepts related to Information Economy.

\section{DATA COLLECTION}

This teaching case was based on semi-structured interviews conducted directly with Relacional's three partners throughout June 2020. This is a real case. However, at the partners' request, the company name and characters have been changed.

Due to the recommended social isolation in the first half of 2020, the interviews were remotely conducted by the authors via Zoom, who took notes during the calls.

\section{RESUMO}

Este caso de ensino aborda a necessidade de mudança na estratégia de negócios da startup Relacional, impulsionada pelos efeitos negativos da pandemia de COVID-19 no setor educacional brasileiro, no primeiro semestre de 2020. A startup é uma desenvolvedora de sistemas de informação que busca solucionar problemas específicos das instituiçôes de ensino, desde o nível básico até o superior, como relacionamento, atração e retenção de alunos. Em meio a um cenário de provável crise no setor, os sócios buscam alternativas de negócio para auxiliar as instituições de ensino ao mesmo passo em que procuram garantir o crescimento e a perenidade da própria empresa. Indicado para aplicação em disciplinas de Empreendedorismo, Marketing e TI em cursos de graduação e pós-graduação em Administração de Empresas, este caso aborda conceitos da Economia da Informaçáo, modelos de oferta e precificação de softwares.

Palavras-chave: tecnologia de informação; CRM; educação; versionamento de software; software como serviço.
Subsequently, the interviewees reviewed this case's text, authorizing it to be published.

Additional secondary data was collected from the company's materials and from public information sources about the Brazilian education industry, such as the Ministry of Education, Inep, and Semesp (Union of the Entities that Maintain Higher Education Companies in the State of São Paulo).

\section{APPLICATION}

This teaching case was designed to be used in undergraduate and graduate Business Administration courses, in subjects such as Entrepreneurship, Marketing, and Information Technology, and may also be used in subjects that deal with business models and product strategy. 


\section{SUPPORT MATERIALS}

It is recommended that participants have an introductory class and/or read the concepts discussed in the book Information rules by Shapiro and Varian (2003), especially chapters 2 (pricing), 3 (versioning), and 7 (network effect).

Additional materials may be used or suggested by the instructor in the preparation and discussion phases, or even after this case is presented:

- Blog post from the Totvs software company on the relevance of CRM for institutions in the educational sector (Totvs, 2019).

- Website of the software company Salesforce in Brazil, one of the pioneers in the SaaS model for CRM systems: https://www.salesforce.com/br/ (retrieved on September 3, 2020).

- Website of the CRM Educacional software company, with studies and products for the educational industry: https://crmeducacional.com/ estudosemateriais/ (retrieved on August 23, 2020).

- Webinar: Top 10 higher education trends: Midway through an unusual year (Gartner, 2021).

- Gartner: The eight building blocks of CRM: Overview (Thompson, 2019).

- Gartner: Strategic roadmap for higher education student information system (Yanckello \& Thayer, 2020).

\section{PREPARATION QUESTIONS}

The preparation questions aim to help participants understand important elements of the case, including technologies and concepts, but which are not directly related to the decision-making process to be discussed in class.

Participants are suggested to perform additional research on the terms and topics, possibly by accessing the supporting materials.

What is the purpose of a customer relationship management (CRM) system? What does it encompass?

- What is a minimum viable product (MVP)? Why would a company launch an incomplete product into the market?
- Considering the current software market, list the primary selling methods, explaining the advantages and disadvantages of each option.

- Does it make sense to invest in the development of new products and launch them in the context of economic downturn and crisis brought about by the pandemic?

- Considering the decision-making moment and the options presented, what would you recommend to the company's partners? Justify your answer.

\section{ANALYSIS OF THE QUESTIONS FOR DISCUSSION}

This teaching case has been written to address primarily the issue of versioning information goods in a market context that involves network growth, barriers to entry, software supply models, and pricing models. Different questions can be addressed to discuss these concepts and theories. In this section, we present the discussion questions articulated in the proposed teaching plan.

What are the differences between these software distribution models: off-the-shelf versus custom, licensed versus Saas?

We suggest starting the discussions by addressing software distribution models and their pricing before addressing Relacional's case. This can be done by comparing real software distribution, such as an antivirus in the market, a system developed specifically for a company, and Google Docs. The goal is to understand that there are at least two dimensions in this initial discussion: degree of customization (scope), which implies customer segmentation; and delivery strategy (template), which involves technological, contractual, and pricing models. To this end, two important conceptual dimensions need to be addressed:

\section{Software distribution models}

There are currently different software distribution models, each one having its advantages and disadvantages. No model is intrinsically better than the other, but a certain design is more adherent to the needs of a client in a specific context.

Off-the-shelf software is conceptualized, developed, and marketed in one or a few versions to serve multiple customers, containing the functionality and features most commonly requested by users. It does not seek to meet 
all customers' needs, but to be a relatively adequate and cheap option, as the variable cost of development and customization is reduced, and the fixed cost is diluted with its widespread sales (Shapiro \& Varian, 2003).

Customized software, or even on-demand software, is built and/or adapted to the specific needs of a client, requiring further development and interaction by the developer. This leads to higher variable costs, which generally imply higher prices. On the other hand, it meets the customer's requirements better than off-the-shelf software, which can offset its high price as it brings better results for the business. The intellectual property of the software usually becomes property of the customer.

Licensed software is a sales model based on the right to use, which can have different pricing forms. In general, the intellectual property of the information asset belongs to the developer, which authorizes its clients to use it.

The SaaS model does not regard software as an information asset, but as a service instead. It has important operational, accounting, and pricing implications. SaaS is commonly implemented in cloud computing, outside the customer's technological domains, and is accessed and used via internet tools and applications. As it is acquired as a service, $\mathrm{SaaS}$ is accounted for as a recurring expense by the client company, reducing the profit of the business and possibly also the taxes to be paid.

\section{Pricing models for information goods}

There are several software pricing models depending on their distribution strategy.

Historically, the most common model is licensing, in which the customer pays a flat fee for the right to legally use the software. This fee can be a one-time, up-front fee (one shot), or a renewable fee after a period, e.g., annually. Generally, the price is determined by the availability and right to use the asset, regardless of actual use.

There are some advantages for customers who adopt this pricing model, such as payment predictability and the possibility of intensive use without incurring additional costs. But there are disadvantages, such as potential idleness or under-utilization of the contracted assets.
Alternatively, in the pay-per-use model, information goods consumed are priced as quantifiable units. This model is also adherent to the strategy of offering SaaS, generally allowing for more dynamic pricing according to the client's specific needs at the time. In addition, it is a fairer pricing model because it adapts the amount paid to the specific needs and uses of each customer, while the flat fee model commonly establishes an average price for everyone.

Finally, there is also a hybrid pricing model called freemium, based on the free basic versions of the service and paid full versions or versions with more features and capabilities. The idea is that free versions lure customers into paying for improved versions when they need more features or performance. To a large extent, this pricing model can accommodate two relatively conflicting growth strategies related to information goods: network growth versus profitable growth. Besides, zero-based pricing models consider that consumers and payers may eventually be different agents in an ecosystem.

From the customer's perspective, the best pricing model is one that minimizes the total cost of ownership (TCO) over time while delivering the business' requirements. In general, an optimized software strategy can combine different models (free, SaaS, or flat fee) depending on customers' needs and effective uses, as illustrated in Figure 1.

Shapiro and Varian (2003) describe three ways of pricing information goods: customized pricing, a unique price for each user; versioning, letting users choose the most appropriate set or version; and pricing by consumer groups. Relacional initially adopted the customized pricing model and assessed the adoption of the versioning model.

At this point, these conceptual dimensions can be analyzed from customers' perspectives, highlighting some variables such as cost (or TCO) and usage (or time), as suggested in Figure 1. 


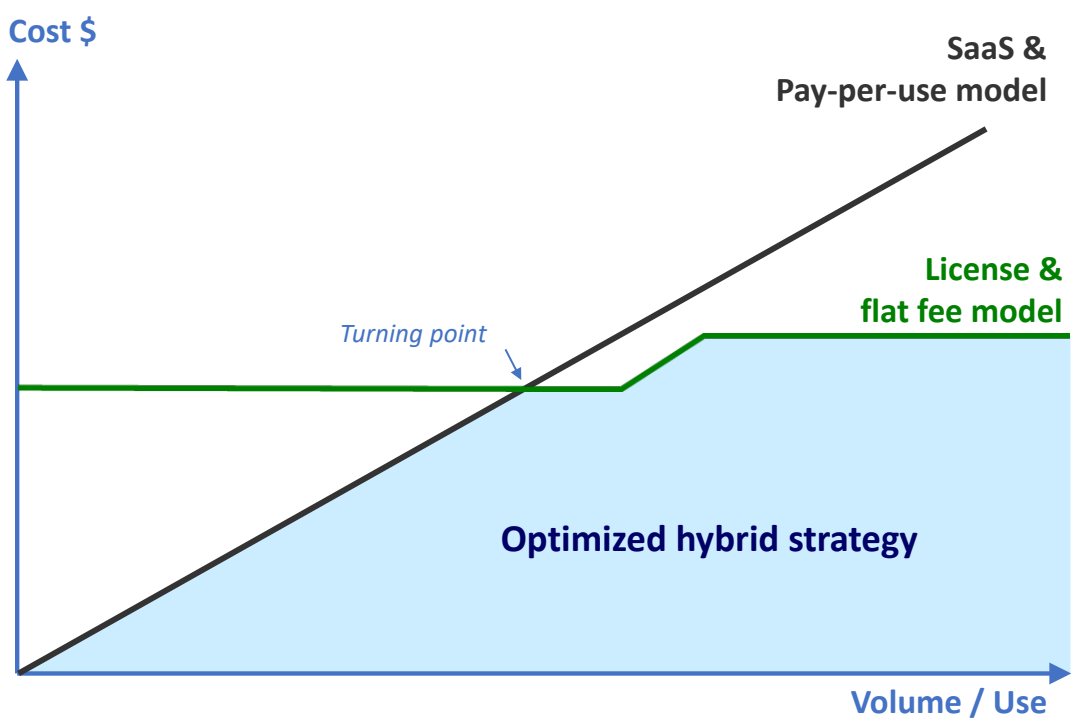

Figure 1. Optimized pricing strategy.

Source: The authors.

In the context of the case, what are the advantages and disadvantages of offering the full CRM system versus fractional services? Evaluate different perspectives: software company, education institutions, vendors, and service and support teams.

Shapiro and Varian (2003) understand that a versioning strategy of information asset allows a company to design its product line, even without knowing the specific needs of each customer. It works appropriately in a network growth strategy, in which different customers with different needs can be served quickly and easily. According to the authors, some dimensions add value for customers and can be drivers for versioning, such as agility (of operation and/or implementation), user interface, convenience, flexibility of use, scalability, specific features and functions, and support.

Sordi, Nelson, Meireles and Silveira (2016) describe multiple perceptions regarding the versioning of digital products and services, adding to their review the dimensions of availability, integrity, and scope. According to the authors, information asset versioning needs to take into account the three components of its architecture: content, technology, and processes. From this perspective, one should consider not only 'what' will be versioned, but also 'how' it will be versioned.

The path to versioning is usually designing a superior product first and then remove features in order to build minor versions, depending on customer needs (Shapiro \& Varian, 2003). But it is important not to build minor versions that meet all the needs of a niche market, as this can make the superior versions unfeasible. The authors also discuss how many versions information goods can have in order to maximize the company's results. Although there is no universal rule, "if you cannot decide how many versions to have, or if your market does not segment naturally, choose three" (Shapiro \& Varian, 2003, p. 92). Finally, the authors explain that promotional pricing only makes sense when it helps segment the market and may support the development of the versions, but should be avoided in other situations.

Bhargava and Choudhary (2008) explain that "versioning is profitable when the market share of a lower quality version, when offered alone, exceeds the market share of the high-quality version offered alone" (Bhargava \& Choudhary, 2008, p. 1032). According to them, variable costs influence the decision about versioning by expanding or restricting product lines as variable costs decrease or increase, respectively.

In Relacional's case, there are some advantages in maintaining the offer of the full CRM system, such as higher profitability for Relacional; integration of the educational institutions' processes; high service-level agreement (SLA) with customized technical support and service; higher satisfaction of the sales force; and support and service teams already adequate to the business model, being agile and effective. 
However, there are some disadvantages or challenges in maintaining the offer of the full CRM system: limited sales reach, with possible termination of contracts; difficulty in implementing the most robust system; high TCO; difficulty in acquiring new customers during the pandemic; difficult on-site assistance; etc.

Regarding fractioning the services in SaaS models, some advantages stand out: reaching new clients in segments not yet served; reduced TCO, with accounting advantages; quick implementation; self-service acquisition and support; etc.
However, some disadvantages are worrying: potential cannibalization between the company's products, with possible revenue reduction; difficulty in making new sales to customers already served in what they consider essential; decreased service level (SLA) in the self-service model; dissatisfaction of the sales team, because the new sales can be made through the website or even via external channels; need to develop a new selfservice model; and limited support.

It is suggested to register on the board all the participants' contributions, in charts that allow easy comparison, as suggested in Figure 2.

\begin{tabular}{|l|c|c|c|c|}
\hline & \multicolumn{2}{|c|}{ Complete CRM System } & \multicolumn{2}{c|}{ System fractions via SaaS } \\
\hline Perspective: & Advantages & Disadvantages & Advantages & Disadvantages \\
\hline Relacional & Higher profitability & Decreased sales & $\begin{array}{c}\text { Increased sales, new customer } \\
\text { segments }\end{array}$ & $\begin{array}{c}\text { Potential cannibalization with } \\
\text { reduced revenue }\end{array}$ \\
\hline $\begin{array}{l}\text { Education } \\
\text { institution }\end{array}$ & $\begin{array}{c}\text { Process integration, higher } \\
\text { SLA }\end{array}$ & Increased TCO & $\begin{array}{c}\text { Decreased TCO, accounting } \\
\text { advantages }\end{array}$ & Decreased SLA \\
\hline Sales team & $\begin{array}{c}\text { Increased satisfaction and } \\
\text { compensation }\end{array}$ & $\begin{array}{c}\text { Decreased sales during the } \\
\text { pandemic }\end{array}$ & $\begin{array}{c}\text { Dissatisfaction, difficult to } \\
\text { increase average ticket }\end{array}$ \\
\hline $\begin{array}{l}\text { Customer Service } \\
\& \text { Support }\end{array}$ & $\begin{array}{c}\text { Adequate teams and models } \\
\text {... }\end{array}$ & Difficulty to serve on-site & Self-service model & $\begin{array}{c}\text { Limited and time-consuming } \\
\text { technical support }\end{array}$ \\
\hline
\end{tabular}

Figure 2. Comparative analysis between the distribution models.

Source: The authors.

\section{Can conflicting product strategies coexist, in this case, by offering a complete CRM system and fractional services?}

The theory applied to this case discusses the versioning of information goods and services, considering the coexistence of different offers, strategies, and target audiences. But it also warns about possible cannibalization in product lines, which is very worrying for the business. To avoid this, Shapiro and Varian (2003) recommend reducing the price of the superior version, satisfying current and new specialized customers, along with a reduction in the quality/ scope of the minor versions, thus creating subtracted-value versions suitable for new customers. For example, versions of a program without personal technical support can be marketed at reduced prices.
On the choice of marketing channels for versioned information goods, Liu, Li and Kou (2015) conclude that:

"A supplier prefers the versioning strategy when network externality exists in the market, whereas the single-version strategy is more preferable for an information product when network externality does not exist in the market. When two versions are released in a market with network externality, the best sale channel strategy is that the highquality version is distributed through the direct sale channel and the low-quality version is sold through the retailing channel" (Liu, Li, \& Kou, 2015, p. 1). 
In practice, this issue should be analyzed with the intended audiences of the offerings in mind, that is, whichever adds more value for customers in different dimensions. If you have the same audience and value proposition, perhaps cannibalization will be broad and very harmful to the company, since one of the distribution models will be less adherent to customers' needs. If you have different audiences in different market segments, the information goods' value proposition may be based on other dimensions, making cannibalization less likely. In this case, the coexistence of multiple offers by the company to the market would be possible.

In the event of cannibalization, the offering company should create policies and controls to minimize negative impacts, such as managing sales channel conflicts, encouraging the acquisition of complementary services, etc.

In addition, the company should estimate whether the new target audience to be served - with a simpler or more robust version of the information asset - represents a large and profitable enough market to justify expanding more than one front of attack (Bhargava \& Choudhary, 2008). Software companies operating in the Brazilian education market have already adopted the versioning strategy in their products (Totvs, 2019).

Throughout this still theoretical discussion, Relacional's case may come up, allowing the instructor to reverse the order of the next two questions.

\section{Which growth model makes the most sense for Relacional in its scenario?}

In Relacional's case, its mission and value proposition are not only related to offering a CRM system for education institutions, but anticipating solutions for upcoming problems in the industry. In the context of the COVID-19 pandemic, with intense and painful impacts on the educational industry (Ker \& Motoda, 2020), it makes even more sense for Relacional to tailor its offer of solutions to the immediate needs of clients. In this regard, at least three scenarios need to be analyzed: (A) maintain only the offer of the full CRM with its modules, (B) expand the offer with SaaS services, or (C) migrate the full operation to the latter model.

In scenario $A$, the company neither changes nor supports educational institutions in this critical moment, wasting the opportunity to expand its operations, and may even lose customers and income due to the likely market downturn.
In scenarios $\mathrm{B}$ and $\mathrm{C}$, the company needs to develop a new business model, complementing or replacing the current one, with significant impacts on the marketing model (and direct sales force), pricing and operational revenues (scheduled, not upfront or one-shot), development and support, customer service processes, etc.

It is clear that scenarios $\mathrm{B}$ or $\mathrm{C}$ make more sense in this context, which can be presented in another way: Offer SaaS only, or offer the full CRM system as well? To answer this, we return to the previous question: the target audience for SaaS services seems to be fairly distinct from the company's current customers, in view of the recent acquisition of new customers during the pandemic. In this case, cannibalization would be less intense or damaging, indicating that it is a good idea to maintain both strategies. Given that several institutions can adopt the optimal hybrid strategy (Figure 1), Relacional can seize the opportunity to offer and be the choice of customers at any point in time and at any level of maturity of its business.

And given that the potential new market for 'fractional' SaaS services appears to be large according to industry data, there may be network externality in this market, which would support the versioning strategy (Liu et al., 2015), allowing for network growth with different customer needs being met quickly and easily (Shapiro \& Varian, 2003).

Since the education market is quite heterogeneous, with different institutions requiring varied technological solutions for their specific needs, the a priori segmentation of this industry is relatively difficult, which justifies a versioning strategy with fractionation of the full system (Shapiro \& Varian, 2003). In this sense, the company should take into account variations in the sales method (technology) and additional services (processes), more than variations in the functionality of services (content), as indicated by Sordi et al. (2016).

Finally, the required changes in this process are quite deep and significant. Migrating the current business model only makes sense if such changes are valuable and permanent in the medium and long term. 


\section{As a consultant serving Relacional, what recommendation would you give to the partners? Justify your recommendation and prepare an action plan for the company.}

One of the key strategies for a technology startup is network growth. The network effect is a phenomenon that occurs in some digital business models, often related to the positive feedback concept. Shapiro and Varian (2003) explain that adding more members to a given business entails increased value for all users, which attracts even more members.

In Relacional's case, the network effect could accelerate the expansion of its customer network, as its predictive algorithms can be continuously improved based on processed data from a growing number of customers. With high-performance predictive models, more customers are attracted, including to contract different services from the company, feeding this cycle backwards. Data is protected all the time, remaining as property of educational institutions; but learning via the improvement of algorithms can and should be encouraged by the companies that process the data.

At a later stage, Relacional's systems and services could become references or even market standards, allowing the construction of barriers to competitors. "The aura of inevitability is a powerful weapon when demand-side economies of scale are strong" (Shapiro \& Varian, 2003, p. 213). In a way, this is what happens with the urban mobility app Waze: any company can create a similar app, but the continuous database feeding, with more and more users, makes it very difficult to surpass its level of service perceived by customers.

This question enables complementary discussions. Inaction is ruled out due to the need for business growth and continuity. The option to migrate directly to fractional SaaS services enables exclusive focus on this new model but kills value with current customers. Choosing to have a hybrid strategy makes sense, both to foster network growth and to ensure sustainability via the current model. It is also consistent with the hybrid strategies of customers: start with SaaS and migrate to other models in due course (Figure 1). In this case, Relacional would serve clients at different degrees of maturity and different business models. In practice, this would imply expanding the company precisely at a crisis!

When developing action plans, conflicts must be managed (cannibalization, sales force, customer service) and externalities must be taken advantage of, considering the different moments and value propositions for clients.

\section{SUGGESTED TEACHING PLAN}

Introduction (10 minutes): If not previously requested, the instructor may suggest that the 'preparation questions' be discussed in small groups, in order to level knowledge about concepts and terms that will be addressed in the discussion. If pertinent, the instructor may present Relacional and its competitors' websites, highlighting the most relevant elements.

Difference between software delivery and pricing models (15 minutes): Before discussing the central issue - versioning - , the instructor can build, with the participants, comparative charts on the board, highlighting the characteristics and differences between off-the-shelf and customized software; licensed and SaaS; flat-fee, usage, and freemium pricing. We suggest the instructor asks the participants for examples of each modality.

Versioning information goods ( 25 minutes): In this step, having discussed the models of software distribution, the instructor can lead the discussions about the advantages and disadvantages of maintaining the current offer of the full CRM system against the opportunities and risks of offering fractional services, considering the different stakeholders' perspectives. It is expected that participants question whether the software distribution strategies are mutually exclusive, a suitable moment in which the instructor can return the question: In Relacional's case, could different product strategies coexist? Such a question will induce participants to the next discussion.

Long-term strategy (10 minutes): Considering the pros and cons of the software distribution models evaluated in the pandemic context, a new question arises: Is the change studied for the company a temporary response or a strategy that will be maintained in the long term? In other words, is it feasible to go back to the context before the pandemic, considering that new customers have been acquired with new services? If the discussion ends quickly, additional questions can be proposed, such as: What would make a customer migrate from the on-demand SaaS model to purchasing the full version of the system?

Decision and action plan (15 minutes): After discussing the methods and contexts, the instructor can move the discussions toward a conclusion by asking different participants about their decisions: If you were a consultant to the company, what recommendation would you give to Relacional's partners? There may be polarized opinions, which can be broken down by prompting the participants to explain "how exactly to conduct the implementation of the company's product strategy", i.e., 
by explaining in general terms their action plans. It is expected that opinions will be more diverse on the "how to do it" than on the "what to do."

Wrap-up (10 minutes): To end the meeting, the instructor can briefly summarize the concepts, models, and strategies discussed. The participants can be asked to explain the primary lessons learned from the case discussion.

At the end of the discussion session, the participants' contributions can be organized on the board according to Figure 3.

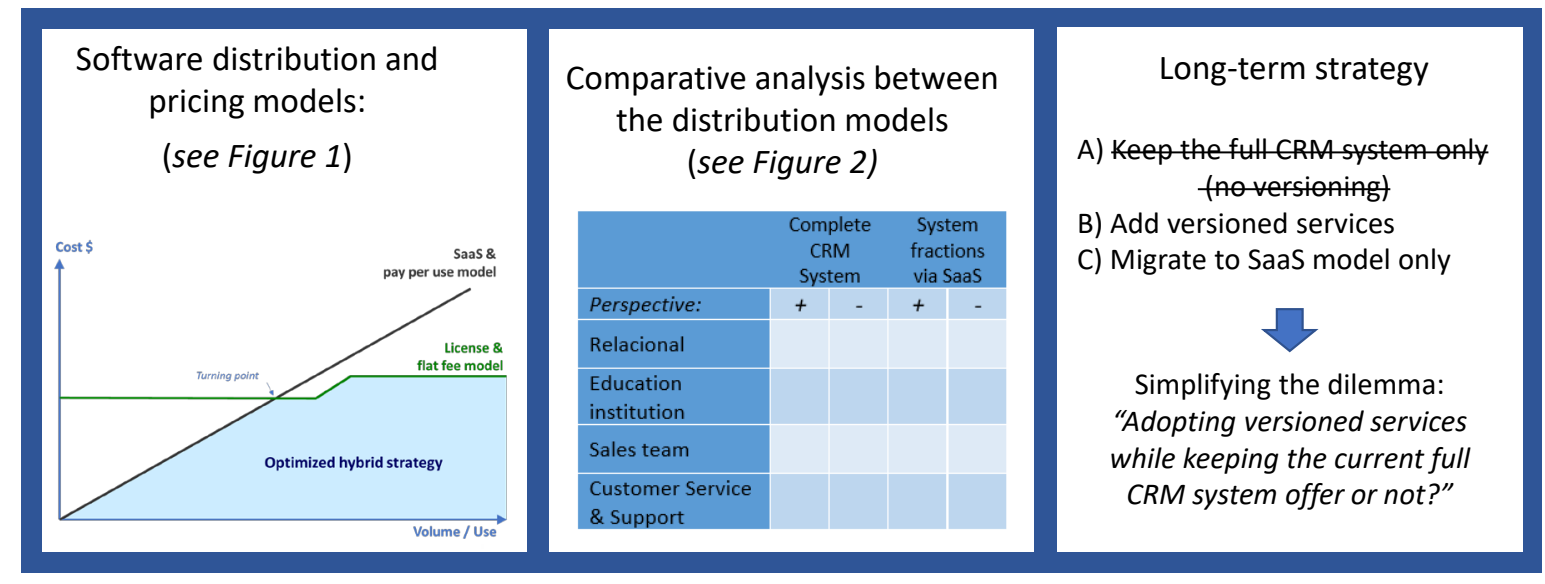

Figure 3. Suggested recording of the discussions on the board.

Source: The authors.

\section{CASE DEVELOPMENTS}

In July 2020, the company partners reached a conclusion: more than wished, versioning the system into smaller, more focused services was essential, so customers would perceive value easily. Even if there was some cannibalization among the products offered by the company, "at least the client would still be ours," said one of the partners. In this sense, the business strategy would be focused on network growth with new customer attraction, especially due to the intense crisis in the industry as a result of the COVID-19 pandemic. Once again, Relacional would anticipate its clients' pains, knowing that this would have important consequences on its organizational structure, especially on the sales, development, and support areas.

Before the beginning of the second semester of 2020, the company had already implemented the following versioning:

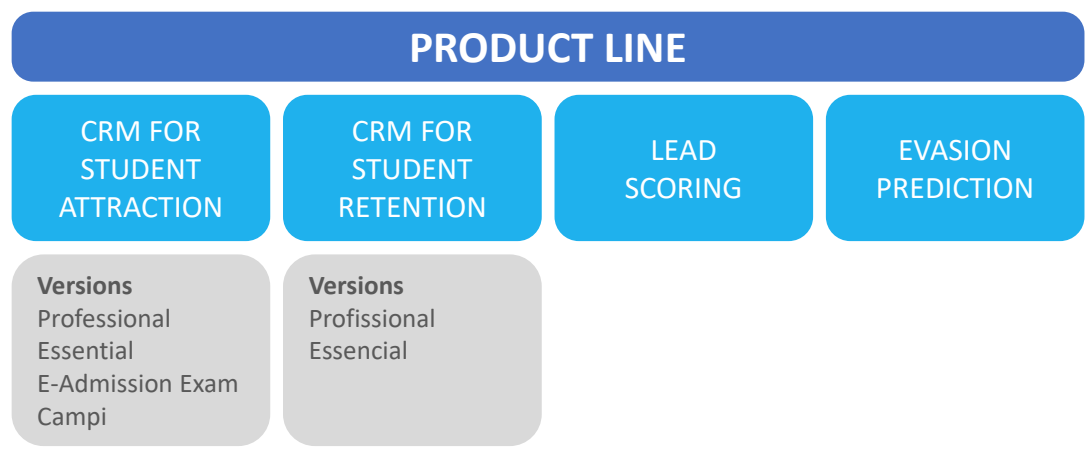

Figure 4. Software versions in July 2020. Source: The authors. 
With their successful product versioning strategy in the Brazilian market, in early 2021 the partners were evaluating the possibility of internationalizing the company. A preliminary study identified similar needs in several Latin American education institutions, which could be remotely supplied by Relacional's products already offered via SaaS, with low investment in translation and technical adaptation.

\section{REFERENCES}

Bhargava, H. K., \& Choudhary, V. (2008). When is versioning optimal for information goods? Management Science, 54(5), 1029-1035. https://doi.org/10.1287/mnsc.1070.0773

Gartner. (2021). Top 10 higher education trends: Midway through an unusual year. Retrieved from https://www.gartner.com/ webinar $/ 3985865 /$ player?commId $=415680 \&$ channelId $=$ 15915\&srcId=0-0000000000\&webinarType $=$ ondemand

Ker, J., \& Motoda, E. (2020, July 06). Em dois meses, 265 mil alunos abandonaram a graduação, diz sindicato de mantenedoras. Estadão. Retrieved from https://educacao. estadao.com.br/noticias/geral,em-dois-meses-265-milalunos-abandonaram-a-graduacao-diz-sindicato-demantenedoras, 70003354874

Liu, Z., Li, M., \& Kou, J. (2015). Selling information products: Sale channel selection and versioning strategy with network externality. International Journal of Production Economics, 166, 1-10. https://doi.org/10.1016/j.ijpe.2015.04.006

Shapiro, C., \& Varian, H. R. (2003). A economia da informação: Como os princípios econômicos se aplicam à era da internet. Rio de Janeiro: Elsevier.
Sordi, J. O. de., Nelson, R. E., Meireles, M., \& Silveira, M. A. da (2016). Development of digital products and services: Proposal of a framework to analyze versioning actions. European Management Journal, 34(5), 564578. https://doi.org/10.1016/j.emj.2016.01.009

Thompson, E. (2019, May 16). The eight building blocks of CRM: Overview. Gartner. Retrieved from https://www.gartner. com/en/documents/3913640/the-eight-building-blocksof-crm-overview

Totvs. (2019, December 26). CRM Educacional: Essencial para as instituiçóes de ensino. Recuperado de: https://www.totvs. com/blog/instituicao-de-ensino/crm-educacional/

Yanckello, R., \& Thayer, T. (2020, April 28). Strategic roadmap for higher education student information system. Gartner. Retrieved from https://www.gartner.com/en/ documents/3984281/2020-strategic-roadmap-for-highereducation-student-info 


\section{Authorship}

\section{Adrian Kemmer Cernev*}

Fundação Getulio Vargas, Escola de Administração de Empresas de São Paulo

Rua Itapeva, no 474, Bela Vista, 01313-902, São Paulo, SP, Brazil

E-mail address: adrian.cernev@fgv.br

(1) https://orcid.org/0000-0002-6300-3976

\section{Letícia Fantinato Menegon}

Fundação Getulio Vargas, Escola de Administração de Empresas de São Paulo

Rua Itapeva, no 474, Bela Vista, 01313-902, São Paulo, SP, Brazil

Escola Superior de Propaganda e Marketing

Rua Dr. Álvaro Alvim, n. 123, Vila Mariana, 04018-010, São

Paulo, SP, Brazil

E-mail address: leticia.menegon@fgv.br

(1) https://orcid.org/0000-0002-0008-078X

\section{Marta de Campos Maia}

Fundação Getulio Vargas, Escola de Administração de Empresas de São Paulo

Rua Itapeva, no 474, Bela Vista, 01313-902, São Paulo, SP, Brazil

E-mail address: marta.maia@fgv.br

(1) https://orcid.org/0000-0002-9479-0693

* Corresponding Author

\section{Funding}

The authors reported that there is no financial support for the research in this article.

\section{Conflict of Interests}

The authors have stated that there is no conflict of interest.

\section{Copyrights}

RAC owns the copyright to this content.

\section{Authors' Contributions}

$1^{\text {st }}$ author: conceptualization (equal); data curation (equal); formal analysis (lead); investigation (equal); methodology (equal); project administration (equal); resources (equal); supervision (equal); validation (equal); writing-original draft (equal); writing-review \& editing (lead).

$2^{\text {nd }}$ author: conceptualization (lead); data curation (equal); formal analysis (equal); investigation (equal); methodology (equal); project administration (equal); resources (equal); supervision (equal); validation (lead); writing-original draft (equal); writing-review \& editing (lead).

$3^{\text {rd }}$ author: data curation (equal); investigation (supporting); validation (supporting); visualization (equal); writing-original draft (supporting).

\section{Plagiarism Check}

The RAC maintains the practice of submitting all documents approved for publication to the plagiarism check, using specific tools, e.g.: iThenticate.

\section{Peer Review Method}

This content was evaluated using the double-blind peer review process. The disclosure of the reviewers' information on the first page, as well as the Peer Review Report, is made only after concluding the evaluation process, and with the voluntary consent of the respective reviewers and authors.

\section{Data Availability}

RAC encourages data sharing but, in compliance with ethical principles, it does not demand the disclosure of any means of identifying research subjects, preserving the privacy of research subjects. The practice of open data is to enable the reproducibility of results, and to ensure the unrestricted transparency of the results of the published research, without requiring the identity of research subjects. 